\title{
Impacts of near-future ocean warming on microbial community composition of the stomach of the soft-bottom sea star Luidia clathrata (Say) (Echinodermata: Asteroidea)
}

Michelle D Curtis ( $\nabla$ curtismi@uab.edu )

The University of Alabama at Birmingham https://orcid.org/0000-0001-8360-8991

\section{Casey D Morrow}

The University of Alabama at Birmingham

James B McClintock

The University of Alabama at Birmingham

\section{Research Article}

Keywords: Asteroidea, climate change, ocean warming, microbiome, 16s, cardiac stomach

Posted Date: March 23rd, 2021

DOI: https://doi.org/10.21203/rs.3.rs-306104/v1

License: (c) (i) This work is licensed under a Creative Commons Attribution 4.0 International License.

Read Full License 


\section{Abstract}

There is growing evidence that environmental changes caused by climate change can impact the microbiome of marine invertebrates. Such changes can have important implications for the overall health of the host. In the present study we investigated the impact of chronic exposure to an ambient $\left(28^{\circ} \mathrm{C}\right)$ and a predicted mid- $\left(30^{\circ} \mathrm{C}\right)$ and end-of-century $\left(32^{\circ} \mathrm{C}\right)$ seawater temperature on microbiome modification in tissues of the cardiac stomach of the abundant predatory sea star Luidia clathrata collected in September 2018 from Apalachee Bay, Florida $\left(29^{\circ} 58^{\prime} \mathrm{N}, 84^{\circ} 19^{\prime} \mathrm{W}\right)$ in the northern Gulf of Mexico (GOM). Diversity (Shannon index) was lowest among the microbial community of stomach tissue when compared to the microbiome of the artificial sea star feed, and aquarium sand and seawater across all three experimental temperature treatments. Moreover, the stomach microbial community composition was distinct between each of the four sample types. Exposure to the highest experimental temperature treatment $\left(32^{\circ} \mathrm{C}\right)$ resulted in a significant modification of the composition of the microbial community in stomach and sand samples, but not in seawater samples when compared to those from the current mean ambient GOM temperature $\left(28^{\circ} \mathrm{C}\right)$. Importantly, at the most elevated temperature the stomach microbiome shifted from a Vibrio sp. dominated community to a more diverse community with higher proportions of additional taxa including Delftia sp. and Pseudomonas sp. This microbiome shift could impact the digestive functionality and ultimately the health of L. clathrata, a key soft-bottom predator in the northern GOM.

\section{Introduction}

Mean ocean surface temperatures have risen approximately $0.6^{\circ} \mathrm{C}$ over the last century due to global climate change and are projected to warm up to $4^{\circ} \mathrm{C}$ by the year 2100 (IPCC, 2019). This warming has already impacted the structure of benthic marine invertebrate communities by forcing shifts in geographic distributions of various species (Schiel et al. 2004; Parmesan 2006), introducing non-native species (Przeslawski et al. 2008), and decreasing fitness of select species subject to thermal stress (Pörtner 2008). Ectothermic marine invertebrates living in shallow waters at or near their upper thermal tolerance are most at risk for deleterious impacts with continued ocean warming (Pörtner 2002; Peck et al. 2008).

Ocean warming has also been linked to increased prevalence of marine pathogens (Harvell et al. 2002) and as a result some organisms are increasingly susceptible to disease. This is particularly the case in marine ectotherms including sea urchins and sea stars (Tracy et al. 2019). For example, the large, multiarmed predatory sea star Pycnopodia helianthoides has experienced widescale population declines along the Pacific coast of North America resulting from an outbreak of sea star wasting disease thought to be linked to ocean warming (Harvell et al. 2019). Ocean warming has also been associated with increased morbidity and mortality from disease in the keystone sea star Pisaster ochraceus (Bates et al. 2009; Eisenlord et al. 2016; Kohl et al. 2016). Exposure to increased seawater temperature can induce more benign impacts in stars including accelerated growth and elevated feeding rates (Watts and Lawrence 1986, 1990; Eckert et al. 2000; Gooding et al. 2009; Fly et al. 2012; Monaco et al. 2014). However, 
sublethal stress impacts from elevated temperature may also occur including higher metabolic demand, decreased immune response (Watts and Lawrence 1986, 1990), and arm autotomy in sea stars (Barker et al. 1992; Haramoto et al. 2007; Barker and Scheibling 2008).

Microbial communities impact a variety of aspects of host physiological function through their influence on host behavior, contribution to metabolic functioning, and maintenance or enhancement of immune response (reviewed in Holmes et al. 2011; Kinross et al. 2011; Vuong et al. 2017). Conversely, microbial community dynamics are affected by the genetics, behavior, and physiological state of the host (Spor et al. 2011; Foster et al. 2015; Gomez et al. 2017). This delicate balance between host-microbiome interactions can be disrupted by changes in host physiology or by changes in the external environment (Lynch and Hsiao 2019). Disruption of this balance can have deleterious consequences for the host, which may in turn lead to significant ecological impacts if the host is an important player in the community. A recent example of host-microbiome discordance with ecological implications is illustrated by the negative impacts of sea star wasting disease on the epidermal microbiome of the keystone sea star Pisaster ochraceus. Lloyd and Pespeni (2018) reported a decrease in overall epidermal microbial species richness in $P$. ochraceus, suggesting a shift away from bacterial taxa with functional attributes that supported an immune response to pathogenic microbial typical of sea star wasting disease. In a separate comparative study, disease progression similarly led to a shift in the microbial community structure of the gonad, body wall, tube feet, and pyloric ceca of four species of coralivorous crown-ofthorns sea stars in the genus Acanthaster (Høj et al. 2018).

The microbial community of the vertebrate gut also plays a crucial role in host-microbiome dynamics and host health (Kinross et al. 2011; D'Argenio and Salvatore 2015; Shreiner et al. 2015). The same key roles of microbes are likely to occur in marine invertebrate digestive systems. For example, Brothers et al. (2018) found that chronic exposure to an elevated seawater temperature aligned with predicted nearfuture ocean warming significantly altered the presumptive functionality of the gut microbiome of the common subtropical sea urchin Lytechinus variegatus. Importantly, Brothers et al. (2018) found that the predicted microbial metagenomics impacted were those related to host physiological processes of membrane transport and metabolism of amino acids and carbohydrates, suggesting that individuals are likely to face physiological challenges as seawater temperatures continue to rise. Moreover, $L$. variegatus evaluated in this study were collected from the northern Gulf of Mexico (GOM) where population migration northward to escape currently rising seawater temperature is not feasible. If the ultimate outcome of changes in host microbiome structure and functionality is an increase in sub-lethal or lethal impacts on ecologically important species such as sea urchins and sea stars, then there will be important downstream ecological consequences on benthic community structure. Despite the potential significance of rapid anthropogenic climate warming impacting the gut microbiome of a model representative sea urchin that plays a key role in seagrass ecology (Brothers et al. 2018), to date, no studies have similarly examined temperature-sensitivity of the gut (stomach) microbiome of a model sea star.

Luidia clathrata is a key predatory, soft-bottom sea star in the family Luidiidae that has the appropriate attributes to make it a model species for the study of the impacts of ocean warming on the stomach 
microbiome. The species is widely distributed and can be found in abundance in near-shore habitats throughout the GOM, as well as nearshore regions of the southeastern Atlantic coast of the U.S. north to North Carolina, coastal environments of northeastern South America, and throughout the Caribbean (Hendler 1995; Lawrence 2013; Lawrence et al. 2013). Its high abundance in shallow (< $40 \mathrm{~m}$ depth), protected, bays along the northern $\mathrm{GOM}$, a region projected to experience disproportionately high rates of ocean warming and lacking northward refugia (Przeslawski et al. 2008). Accordingly, L. clathrata sampled from this region provide an excellent model for the examination of prospective climate-induced impacts of ocean warming.

In contrast to the complex intestinal tract of the sea urchin L. variegatus (Holland 2013), the digestive morphology of L. clathrata is comparatively simple. Essentially the digestive system consists of the mouth, cardiac stomach, and five pyloric ceca, the latter used largely in final digestive processes and nutrient storage (Jangoux 1982). Unlike many sea stars that extrude the cardiac stomach from the mouth, members of Luidiidae are generally considered to feed intraorally by depressing the oral disc into the sediment and guiding prey into the mouth with the tube feet (McClintock and Lawrence 1981). Interestingly, McClintock et al. (1983) observed extraoral feeding in L. clathrata via a modest extrusion of the cardiac stomach both in the field and under experimental laboratory conditions. In the latter case, powdered food added to sand induced extraoral feeding. A capacity for extraoral feeding distinguishes $L$. clathrata from other luidiid sea stars in that it allows for the exploitation of detrital food resources in addition to infaunal and epifaunal prey.

Despite the established importance of the microbiome in host health and the presumption that the impacts of climate change-induced temperature stress are likely to have negative impacts on aspects of whole animal physiology and behavior, current knowledge of how near-future ocean warming may impact host microbial community structure in marine invertebrates is largely lacking. The purpose of the present study was to experimentally evaluate the potential effects of chronic exposure to predicted near-future seawater temperatures on the stomach microbiome of the common sea star L. clathrata sampled from a population in the northern GOM where there no refugia from rising seawater temperatures.

\section{Material And Methods}

\section{Acquisition and Husbandry}

Adult, non arm-regenerating Luidia clathrata (mean arm radius $(\mathrm{R}) \pm \mathrm{SE}=65.2 \pm 1.8 \mathrm{~mm}, \mathrm{n}=30$ ) were collected by standard otter trawl ( $1 \mathrm{~cm}$ mesh size) from Apalachee Bay, Florida $\left(29^{\circ} 58^{\prime} \mathrm{N}, 84^{\circ} 19^{\prime} \mathrm{W}\right)$ in early September, 2018. Immediately following collection, each individual was placed individually into a plastic bag containing ambient seawater. The bags containing sea stars were placed into 80-L LoBoy ${ }^{\odot}$ Styrofoam coolers (10 bagged sea stars/cooler) and shipped overnight to the University of Alabama at Birmingham (UAB). Each cooler was supplied with two 1-lb frozen gel ice packs (ChillPak ${ }^{\odot}$, Greiner BioOne International). Upon arrival at UAB, sea stars were transported to a climate-controlled room. Bags containing individual sea stars and the seawater they were collected from were immediately floated in 
seawater in experimental tanks at a temperature of $25^{\circ} \mathrm{C}$. The room was placed on a $12: 12 \mathrm{~h}$ light-dark cycle for the duration of an adjustment period (see below) and throughout the subsequent experiment.

To facilitate gradual acclimatization to experimental tank conditions, the seawater in each plastic bag containing a sea star was replaced with artificial seawater $\left(25^{\circ} \mathrm{C}\right.$, salinity 27 ; previously prepared with Instant Ocean ${ }^{\circledR}$ mixed with reverse-osmosis water filtered through a 4-stage Aquafx Barracuda RO/DI filtration system). Seawater replacements were carried out over a period of $3 \mathrm{~h}$ via a series of repeated seawater exchanges. Following this adjustment period, each of the 30 individuals was randomly assigned (using a random number generator in Microsoft Excel) to fifteen 38-L glass aquaria each divided equally (each half $=25.4 \times 12.7 \times 30.5 \mathrm{~cm}$ ) by a solid plexiglass plate that was sealed in place with standard aquarium silicone sealant. For purposes of clarity, 'half aquaria' will hereafter be referred to as 'separate aquaria'. Accordingly, the final assignment of sea stars was one individual per aquarium. Temperature was maintained in aquaria for each of three temperature treatments by submerging aquaria in large, oval water baths $(99 \times 147 \times 61 \mathrm{~cm})$ consisting of 568-L Rubbermaid ${ }^{\circledR}$ structural foam stock pools perched on cement blocks. Water temperature in each of the three water baths was controlled using a submersible aquarium heater (EHEIM Jager 250 W TruTemp). Each aquarium was supplied with a 3-cm deep layer of fine-grain sand (Nature's Ocean ${ }^{\circledR}$ Substrate, Marine White), a re-circulating water pump (Aqueon ${ }^{\circledR}$ Power Filter 10), and air line tubing with an air stone driven by a Coralife ${ }^{\circledR}$ Super Luft SL-65 high pressure aquarium pump.

Sea stars were held in their respective aquaria at $25^{\circ} \mathrm{C}$ for a two-week holding period without food prior to initiating the experiment. This allowed individuals to adjust to the aquaria and to standardize their nutritional state. Throughout this two-week period and over the subsequent holding period and experiments, water temperature, salinity, and dissolved oxygen were monitored daily using a YSI ${ }^{\text {Tw }}$ ProPlus meter. Moreover, to evaluate and maintain water quality, nitrate, nitrite, ammonia, and pH levels were measured weekly with an $\mathrm{API}^{\mathrm{Im}}$ Aquarium Pharmaceuticals liquid test kit. Large (1/3 aquarium volume), water exchanges were conducted weekly, and smaller water exchanges were conducted as necessary.

Following the initial two-week holding period, the water temperature in all three water baths was slowly elevated from 25 to $28^{\circ} \mathrm{C}$ over a period of 34 days. During this period, and during the subsequent three temperature exposure treatments, each sea star was fed an ad libitum diet of formulated sea star feed (formulation of feed provided by Addison Lawrence, Texas A\&M University). Feed was proffered to each individual every three days and food not consumed within a 14-h period was removed from each aquarium by gloved hand. During this 34-day temperature adjustment period there were a small number of sea stars in the aquaria that suffered mortality: one in one water bath, and two in each of the other two water baths.

Prior to initiating experimental temperature treatments, three Time-Zero groups of two individuals from each of the three water baths ( $n=2 \times 3$ water baths $=6$ sea stars) were randomly selected using the random number generator in Microsoft Excel to establish a baseline microbial community. The cardiac stomach of each sea star was excised by lifting the stomach tissue with sterile forceps and then cutting it 
free with sterile, dissecting scissors. Samples of sand and seawater were simultaneously collected from each aquarium to evaluate their associated microbial communities as controls. The sand samples were each collected by scraping sand into a sterile $50 \mathrm{~mL}$ falcon tube. Each sand sample was processed by using a sterilized scoopula to collect approximately $1 \mathrm{~g}$ wet sand from the center of each falcon tube and transferring it directly into a sterile Eppendorf tube for DNA extraction. Seawater samples were prepared by vacuum filtering $60 \mathrm{~mL}$ of seawater through a sterile, $0.22-\mu \mathrm{m}$, Millipore membrane (EMD Millipore Corporation). Stomach, sand, and seawater samples were all immediately frozen and stored at $-20^{\circ} \mathrm{C}$ until DNA extraction.

Over the following 14 days, water temperatures in two of the three water baths were slowly increased to a projected mid-century $\left(30^{\circ} \mathrm{C}\right)$ and end-of-century $\left(32^{\circ} \mathrm{C}\right)$ ocean temperature based on predictions for the northern GOM (IPCC, 2019). Individuals in the control (ambient) temperature treatment were maintained at $28^{\circ} \mathrm{C}$, the present-time mean July-September in situ temperature for the northern GOM (National Centers for Environmental Information, NOAA). After this 14-day period, all surviving individuals ( $n=7$ of 9,6 of 8 , and 4 of 8 for the $28^{\circ} \mathrm{C}, 30^{\circ} \mathrm{C}$, and $32^{\circ} \mathrm{C}$ temperature treatments, respectively) were dissected and cardiac stomach tissue collected and stored as described above. Importantly, all surviving individuals examined in each temperature treatment appeared healthy and were behaviorally vigorous. Sand and seawater samples were re-collected at the end of the experiment as above for later microbiome DNA extractions, along with three samples of the formulated sea star feed.

\section{Microbial DNA Purification and Sequence Analysis}

Microbial metacommunity DNA was extracted using a Zymo Research Fecal DNA isolation kit (Catalog \# D6010). An amplicon library was constructed with PCR using unique barcoded primers (Kozich et al. 2013; Kumar et al. 2014) to target the hyper variable 4 (V4) region of the 16S rRNA gene (forward primer V4: 5'AATGATACGGCGACCACCGAGATCTACACTATGGTAATTGTGTGCCAGCMGCCGCGGTAA-3'; reverse primer V4:5'-CAAGAGAAGACGGCATACGAGATNNNNNNAGTCAGTCAGCCGGACTACHVGGGTWTCTAAT-3) (Eurofins Genomics, Inc., Huntsville, AL). PCR was conducted with the New England Biolabs LongAmp Taq PCR kit (Catalog \# E5200S) under the conditions outlined in Kumar et al. (2014). PCR products were then electrophoresed on a 1.0\% agarose/TRIS-borate-EDTA gel, visualized by UV illumination, excised, and purified with a Qiagen QIAquick Gel Extraction Kit (Catalog \# 2870) (Kumar et al. 2014).

Purified PCR products were quantified with Pico Green dye, adjusted to a $4 \mathrm{nM}$ concentration, and sequenced on the NextGen sequencing Illumina MiSeq ${ }^{\text {TM }}$ platform using an Illumina paired 250-bp kit (Caporaso et al. 2012; Kozich et al. 2013; Kumar et al. 2014). Two samples were excluded from subsequent analysis due to insufficient PCR product volume, bringing final sample numbers for the $28^{\circ} \mathrm{C}$, $30^{\circ} \mathrm{C}$, and $32^{\circ} \mathrm{C}$ treatments to $(n=6,5$, and 5 , respectively).

The Quantitative Insights into Microbial Ecology package (QIIME2 v2019.10.0; (Bolyen et al. 2019) was used for all downstream data analysis. Demultiplexed sequence data was checked for quality using the DADA2 plugin in QIIME2 (Callahan et al. 2016). Due to a decrease in quality score after 250 nucleotides, the first 13 nucleotides for each forward and reverse read were trimmed and the total read length was 
truncated to 250 nucleotides. Chimeric variants were removed and amplicon sequence variants (ASVs) were identified at a $97 \%$ similarity threshold according to the DADA2 pipeline (Callahan et al. 2016). Taxonomic assignments were made using reference sequences from the SILVA 132 database (Quast et al. 2012) trimmed to the $V 4$ region with the $515 f-806 r$ primers. Representative sequences were classified using the "classify-sklearn" function of the QIIME2 feature-classifier plugin (Bokulich et al. 2018) and nontarget sequences (mitochondria, chloroplast, archaea, eukaryota, unknown) were removed prior to analysis. The remaining sequences were subsampled to a maximum depth of 24,573 to account for variation in read depth using the "alpha-rarefacation" analysis command in the diversity plugin for QIIME2. Rarefaction curves for a-diversity in each sample were generated using the "alpha-rarefaction" command in the Qiime2 diversity plugin. The normalized, rarified ASVs were used for all subsequent analysis (Hakim et al. 2015; Brothers et al. 2018).

\section{Statistical Analyses}

The "core metrics" command in the diversity plugin for QIIME2 was used to calculate microbial diversity of ASVs within each community (a-diversity) and between communities ( $\beta$-diversity). Shannon's index values for a-diversity were compared between time zero and $28^{\circ} \mathrm{C}$ treatments and across all temperature treatments $\left(28^{\circ} \mathrm{C}, 30^{\circ} \mathrm{C}\right.$, and $\left.32^{\circ} \mathrm{C}\right)$ within sample types (cardiac stomach, sand, seawater, and feed) using Kruskal-Wallis test with Benjamini \& Hochberg correction via the "alpha-group-significance" command in the diversity plugin in for QIIME2. $\beta$-diversity was calculated using Bray-Curtis dissimilarity values command for cluster analysis and visualized with principal components analysis (PCoA) using the "diversity core-metrics" command in the diversity plugin for QIIME2. Bray-Curtis dissimilarity values for $\beta$-diversity were compared for each sample type between Time Zero and $28^{\circ} \mathrm{C}$ treatments and across all temperature treatments using permutational multivariate analysis of variance (PERMANOVA) via the "beta-group-significance" command in the diversity plugin for QIIME2. A p-value of $<0.05$ was considered significant for all analyses. A script of all QIIME2 commands used for this study is included as an online resource (see Electronic Supplementary Material 1).

\section{Results}

A total of 6,280,565 16S V4 rRNA gene sequences were initially obtained from sequencing. After denoising, quality filtering, and removing non-target sequences the remaining 3,663,121 sequences were assigned to 3,578 ASVs. Rarefaction curves for a-diversity in each sample leveled off and indicated that all sampling was performed to a sufficient depth to represent microbial community diversity. a-diversity (Shannon Index) was highest in feed, and lowest in stomach tissue overall. Generally, a-diversity increased with increasing temperature in sand, decreased in seawater, and decreased in stomach tissue from $28^{\circ} \mathrm{C}$ to $30^{\circ} \mathrm{C}$, with a sharp increase at $32^{\circ} \mathrm{C}$ (Table 1 ). 
Table 1 Shannon diversity values for all sample types across all temperature treatments. Note: feed samples were taken once at the beginning of the experimental period and all feed was held under constant conditions throughout the experiment.

\begin{tabular}{|lllll|} 
& Time & $28^{\circ} \mathrm{C}$ & $30^{\circ} \mathrm{C}$ & $32^{\circ} \mathrm{C}$ \\
& Zero & & & \\
Feed & $13.54 \pm 0.45$ & & & \\
Seawater & $4.49 \pm 0.95$ & $4.18 \pm 0.92$ & $3.53 \pm 0.30$ & $3.48 \pm 0.43$ \\
Sand & $5.66 \pm 1.43$ & $5.90 \pm 0.42$ & $5.96 \pm 0.46$ & $6.59 \pm 0.43$ \\
Stomach & $1.70 \pm 0.57$ & $1.15 \pm 0.70$ & $0.88 \pm 0.52$ & $2.14 \pm 1.23$ \\
\hline
\end{tabular}

Kruskal-Wallis pairwise comparisons of a-diversity revealed no statistically significant change in microbial diversity of any sample type between time zero and $28^{\circ} \mathrm{C}$ or between any temperature treatment (Table 2).

Table 2 Kruskal-Wallis pairwise significance for seawater, sand, and stomach samples between all temperature treatments. Kruskal-Wallis p-values are shown with Benjamini and Hochberg correction.

\begin{tabular}{lllll|} 
& Time & $28^{\circ} \mathrm{C}-30^{\circ} \mathrm{C}$ & $28^{\circ} \mathrm{C}-32^{\circ} \mathrm{C}$ & $30^{\circ} \mathrm{C}-32^{\circ} \mathrm{C}$ \\
& Zero $-28^{\circ} \mathrm{C}$ & & & \\
Seawater & 0.674 & 0.231 & 0.130 & 0.774 \\
Sand & 0.573 & 0.633 & 0.070 & 0.102 \\
Stomach & 0.140 & 0.518 & 0.231 & 0.072 \\
\hline
\end{tabular}

Vibrio sp., the most abundant ASV overall, represented $40 \%$ of the microbial community across all sample types and treatments. In stomach tissue, Vibrio sp. made up $94 \%$ of the microbial community at $28^{\circ} \mathrm{C}$ and $30^{\circ} \mathrm{C}$ and decreased to $66 \%$ at $32^{\circ} \mathrm{C} \mathrm{(Fig.} \mathrm{1).} \mathrm{Approximately} 98 \%$ of the bacterial community in stomach tissue at $28^{\circ} \mathrm{C}$ was made up of four bacterial taxa: Vibrio sp. (94.25\%), Carboxylicivirga sp. (3.01\%), Delftia sp. (0.36\%), and Halodesulfovibrio sp. (0.31\%) (Fig. 1). Similarly, over $98 \%$ of the bacterial community of stomach tissue at $30^{\circ} \mathrm{C}$ was made up of three bacterial taxa: Vibrio sp. (94.40\%), Delftia sp. (2.62\%), and Pesudomonas sp. (1.39\%) (Fig. 1). The top three bacterial taxa were the same between $30^{\circ} \mathrm{C}$ and $32^{\circ} \mathrm{C}$, but Vibrio sp. abundance decreased, Delftia sp. and Pseudomonas sp. abundance increased, and the top ten most abundant taxa only made up approximately $94 \%$ of the total stomach tissue bacterial community (Fig. 1). The most abundant taxa in the bacterial community of stomach tissue at $32^{\circ} \mathrm{C}$ included: Vibrio sp. (66.34\%), Delftia sp. (11.46\%), Pseudomonas sp. (4.67\%), Halodesulfovibrio sp. (3.99\%), Bacteroides thetaiotaomicron (2.69\%), Bacteroides sp. (1.73\%), Lachnospiraceae NK4A136 group (1.07\%), Clostridium butyricum (0.62\%), Phyllobacterium sp. (0.55\%), and an unidentified member of the kingdom Bacteria (0.37\%) (Fig. 1). 
The seawater bacterial community was primarily dominated by Delftia sp. and Pseudomonas sp., both of which increased in abundance from $28^{\circ} \mathrm{C}\left(29.86 \%\right.$ and $18.33 \%$, respectively), to $30^{\circ} \mathrm{C}(35.54 \%$ and $22.86 \%$, respectively), to $32^{\circ} \mathrm{C}(39.25 \%$ and $25.17 \%$, respectively) (Fig. 1). Phyllobacterium sp. and Methylobacterium sp. were also present with increasing abundance with warming (3.25\% and $1.58 \%$, respectively at $28^{\circ} \mathrm{C}, 4.35 \%$ and $2.14 \%$, respectively at $30^{\circ} \mathrm{C}$, and $4.77 \%$ and $2.60 \%$, respectively at $32^{\circ} \mathrm{C}$ ) (Fig. 1). The most abundant bacterial taxa in sand at $28^{\circ} \mathrm{C}$ were Vibrio sp. (15.42\%), Arcobactersp. (6.42\%), Halodesulfovibrio sp. (5.92\%), Delftia sp. (5.28\%), Photobacterium sp. (4.37\%), and Motiliproteus sp. (3.18\%) (Fig. 1). Vibrio sp. was also the most abundant taxa in sand at $30^{\circ} \mathrm{C}(10.91 \%)$, followed by Delftia sp. (6.67\%), Photobacterium sp. (6.33\%), Propioigenium sp. (4.85\%), Pseudomonas sp. (4.27\%), and Shewanella sp. (3.16\%) (Fig. 1). Photobacterium sp. and Vibrio sp. were also among the top taxa in the sand bacterial community at $32^{\circ} \mathrm{C}(5.95 \%$ and $3.63 \%$, respectively), but the most abundant taxa at this temperature was Motiliproteus sp. (9.07\%) (Fig. 1).

Principal components analysis of Bray-Curtis dissimilarity values showed distinct clustering of microbial community composition by sample type (Fig. 2). Permutational multivariate analysis of variance (PERMANOVA) of Bray-Curtis dissimilarity values revealed significantly different microbial community composition between all sample types $(p=0.001$, stomach-sand, stomach-seawater, stomach-feed, sand-seawater, and sand-feed) except for seawater-feed $(p=0.152)$. Statistically significant changes were observed in microbial community composition between time zero and $28^{\circ} \mathrm{C}$ for sand and seawater, but not for stomach tissue (PERMANOVA; sand $[F=1.855, q=0.036, p=0.030]$, seawater $[F=3.305, q=$ $0.009, p=0.003]$, and stomach $[F=0.710, q=0.731, p=0.731])$.

Importantly, comparison of Bray-Curtis dissimilarity values revealed significant changes in stomach tissue microbial community composition associated with warming between $28^{\circ} \mathrm{C}$ and $32^{\circ} \mathrm{C}$ (PERMANOVA, $\mathrm{F}=2.703, \mathrm{q}=0.045, \mathrm{p}=0.039$ ), but not between $28^{\circ} \mathrm{C}$ and $30^{\circ} \mathrm{C}$ (PERMANOVA, $\mathrm{F}=1.066$, $q=0.322, p=0.318$ ) or between $30^{\circ} \mathrm{C}$ and $32^{\circ} \mathrm{C}$ (PERMANOVA, $F=2.217, q=0.123, p=0.115$ ).

Significant changes in sand microbial community composition were also detected with warming between $28^{\circ} \mathrm{C}$ and $32^{\circ} \mathrm{C}$ and between $30^{\circ} \mathrm{C}$ and $32^{\circ} \mathrm{C}$, but not between $28^{\circ} \mathrm{C}$ and $30^{\circ} \mathrm{C}$ (PERMANOVA; $28^{\circ} \mathrm{C}-32^{\circ} \mathrm{C}[\mathrm{F}$ $=2.621, q=0.020, p=0.013], 30-32^{\circ} \mathrm{C}[\mathrm{F}=1.874, \mathrm{q}=0.017, \mathrm{p}=0.010]$, and $28^{\circ} \mathrm{C}-30^{\circ} \mathrm{C}[\mathrm{F}=1.170, \mathrm{q}=$ $0.216, p=0.208]$ ). No significant difference in microbial community composition of seawater was observed between any of the three temperature treatments (PERMANOVA; $28^{\circ} \mathrm{C}-30^{\circ} \mathrm{C}[\mathrm{F}=1.143, \mathrm{q}=$ $0.252, p=0.246], 28^{\circ} \mathrm{C}-32^{\circ} \mathrm{C}[\mathrm{F}=1.571, \mathrm{q}=0.115, \mathrm{p}=106]$, and $30-32^{\circ} \mathrm{C}[\mathrm{F}=1.235, \mathrm{q}=0.097, \mathrm{p}=$ $0.087])$.

\section{Discussion}

Microbial diversity detected in seawater, sand, and artificial food in the present study were all higher than that detected in the tissues of the cardiac stomach of the star Luidia clathrata. This was particularly evident at experimental seawater temperatures of $28^{\circ} \mathrm{C}$ and $30^{\circ} \mathrm{C}$. The highest levels of microbial diversity occurred in seawater and sand (Table 1). This low level of microbial diversity in the stomach tissues of $L$ clathrata aligns well with other studies of echinoderms which have reported a generally low microbial 
diversity in stomach and digestive tissues of sea urchins (Hakim et al. 2016; Brothers et al. 2018), sea cucumbers (Gao et al. 2014) and sea stars (Jackson et al. 2018). It is also important to note that, similar to the present study, microbial communities characterized from various tissues of 12 species of sea stars have been reported to be distinct from microbial communities of surrounding seawater (Jackson et al. 2018). In the present study, given that extraoral feeding is a common mode of feeding of L. clathrata under laboratory conditions (McClintock et al. 1983) and was also observed throughout the present study, it is not unexpected that the composition of the microbial community in stomach tissue was more closely aligned with that of the sand rather than seawater.

In the present study, the dominant class of bacteria making up the bulk of the microbial communities across all sample types in all three experimental temperature treatments was Gammaproteobacteria. The order Vibrionales dominated the stomach microbial community across all temperatures, while Betaproteobacteriales and Pseudomonadales had the highest abundance in seawater across all temperatures. Samples of aquarium sand had the highest diversity with Vibrionales and Betaproteobacteriales being the two most abundant taxa.

The presence of Vibrio sp. as the primary component of the stomach microbiome in L. clathrata across all three temperature treatments is unique for a sea star. Although high proportion of Vibrio spp. have been reported in the intestine of the sea cucumber Holothuria glaberrima (Pagán-Jiménez et al. 2019), the ophiuroid Ophionema sp. (Dilmore and Hood 1986), and the sea urchins Strongylocentrotus droebachiensis and Tripneustes ventricuosus (Guerinot and Patriquin 1981), we believe ours is the first study to report this pattern in a sea star. Høj et al. (2018) reported small amounts Vibrio sp. in the microbial community of the pyloric cecum of the tropical corallivorous sea star Acanthaster plancii. They also reported a significantly higher incidence of Vibrionaceae-related taxa in diseased individuals than in healthy individuals. Jackson et al. (2018) did not detect Vibrio sp., but reported Tenericutes as the most abundant microbial taxa in the pyloric caeca of the sea stars Pycnopoida helanthoides, Crossaster papposus, Orthasterias koehleri, Pteraster tesselatus, Linckia guildingii, Pentaceraster spp., and Linckia laevigata from the coasts of Washington, USA and Queensland, Australia. A 10- to 20-fold increase in Vibrio sp. and Alteromonas sp. was observed in the microbial communities of food pellets ingested by the sea urchin Lytechinus variegatus held chronically under conditions of near-future warming $\left(30^{\circ} \mathrm{C}\right)$ (Brothers et al. 2018). An opposite trend was observed in the present study, as abundance of Vibrio sp. declined in stomach tissues of $L$. clathrata chronically exposed to an end-of-century warming temperature of $32^{\circ} \mathrm{C}$.

High proportion of bacteria from the Vibrionaceae family is common in gut and stomach tissues of mussels and marine arthropods (Preheim et al. 2011), particularly in crabs (Huq et al. 1986). Additionally, marine copepods reared in an aquarium setting have been shown to have a higher abundance of Vibrio in their gut than copepods from the natural environment (Sochard et al. 1979). Food availability has been reported to affect the gut microbiome of the shrimp Penaeus monodon with higher abundance of Vibrio in the gut of individuals fed to those fed a restricted diet (Simon et al. 2020). Furthermore, Lokmer and Wegner (2015) found thermal stress, but not exposure to Vibrio infection, significantly altered the 
microbiome of the hemolymph of the temperate pacific oyster Crassostrea gigas. As some Vibrio spp. are typically heat-resistant, rapidly growing opportunists (Bourne et al. 2016), it will be interesting to further examine the role of this taxa in the stomach microbiome of luidiid and non-luidiid sea stars to determine if their presence is indicative of disease or stress, or if Vibrio spp. are common members of gut bacterial reservoir communities as seen in other echinoderms and invertebrates more generally (Webster and Thomas 2016; Jackson et al. 2018).

The shift in the stomach microbial community composition of L. clathrata from 94\% Vibrio sp. dominated (as observed in the $28^{\circ} \mathrm{C}$ and $30^{\circ} \mathrm{C}$ treatments) to higher proportions of Delftia sp. and Pseudomonas sp. in the highest temperature treatment $\left(32^{\circ} \mathrm{C}\right)$ is noteworthy. This significant shift in the composition of the stomach's microbial community at the predicted end-of-century temperature for the northern GOM is consistent with that observed in the sea urchin Lytechinus variegatus (Brothers et al. 2018). However, the temperature induced trends for the major microbial taxa present are reversed in these two echinoderms. Brothers et al. (2018) reported that under conditions of near-future warming, the proportion of Vibrio sp. in the gut of $L$. variegatus increased relative to the other microbial taxa. In the present study, the opposite trend in Vibrio sp. occurred with relative abundance trending down with increasing temperature. Pseudomonas is known to possess antibacterial activity (Jayatilake et al. 1996) with one strain reportedly having inhibitory properties against marine pathogenic Vibrio (Chythanya et al. 2002). It is unknown whether the shifts in the microbial communities we observed in the stomach of $L$. clathrata held at elevated temperature are reversible with a reduction in temperature. However, there is evidence this may not be the case. For example, Ramsby et al. (2018) reported a disruption in the microbial community of the tropical sponge Cliona orientalis at $29^{\circ} \mathrm{C}$ and bleaching of Symbiodinium algae at $32^{\circ} \mathrm{C}$, were both irreversible when the sponge was returned to its natural temperature of $23^{\circ} \mathrm{C}$.

Microbial community composition of the tissues of marine invertebrates are critically important both in the context of resistance to disease (Egan and Gardiner 2016; Lloyd and Pespeni 2018). Gudenkauf and Hewson (2015) reported high proportions of both Vibrio sp. and Pseudomonas sp. in body-wall tissues of the Pacific coast sea star Pycnopodia helianthoides infected with sea star wasting disease. In contrast, these same microbial taxa were reported in lower proportions in the body-wall tissues of the Pacific keystone sea star Pisaster ochraceus (Paine 1968) over the documented progression of sea star wasting disease (Lloyd and Pespeni 2018). Gudenkauf and Hewson (2015) suggested that Vibrio sp. and Pseudomonas sp. might represent an active portion of the holobiont that increases rapidly in proportion when host tissues are compromised. Delftia, a genus of gram-negative facultative opportunistic pathogen in the family Comamonadaceae, is known to inhabit marine environments. To date, Delftia has not been reported in sea stars, although this group of gram+ bacteria has been detected in a non-pathogenic form in adults of the hermatypic coral Acropora gemmifera (Zhou et al. 2017). Additionally, Delftia acidovorans has been shown to act as an opportunistic pathogen in European eels held in captivity, co-infecting the eels along with Pseudomonas anguilliseptica (Andree et al. 2013).

In addition to considering the effect of stress-induced gut microbiome modification on overall health, it is also important to consider the potential effects on nutrient processing and metabolism. Brothers et al. 
(2018) detected a significant shift in predicted metabolic and membrane transport functions in the gut microbiome under elevated temperature stress. This observation underlies the importance of understanding how climate change-induced stressors such as ocean warming will affect the gut microbiome and its associated functions. Although little is yet known about the role of the digestive system microbial community in the processes of digestion and metabolism in sea stars, symbiotic gut bacteria are known to play a role in amino acid provision for some terrestrial invertebrates including the potato psyllids (Thao et al. 2000; Arp et al. 2014) and enchytraeid worms (Larsen et al. 2016).

While the present study focused on adult sea stars, it is noteworthy that the microbial community of sea star larvae is distinct from that of the external environment and can display shifts with dietary changes associated with larval growth and development (Carrier et al. 2018). Bipinnaria larvae of Luidia sp. collected from plankton samples in the Northern Atlantic displayed a well-established microbial community with the majority of bacteria isolated to the developing gastric region (Bosch 1992). Bosch (1992) surmised that these symbiotic bacteria were likely associated with digestive processes in the developing larvae. To date, the microbiome of bipinnaria and brachiolaria larvae of L. clathrata is unknown. George et al. (1990) suggested that bacteria, in addition to dissolved nutrients and vitellogenic reserves, might have played a role in nutrition of early development of $L$. clathrata bipinnaria larvae during their laboratory-based experiment. The findings of Bosch (1992) and George et al. (1990) warrant further exploration of the community structure and functional role of the microbiome across larval, juvenile, and adult life history phases in sea star development.

The simple anatomical structure and basal phyletic nature of the genus Luidia provides a unique opportunity for developing an understanding of gut microbiome dynamics in sea stars. Although members of Luidia lack the pyloric stomach found in higher sea star taxa, in addition to predatory foraging L. clathrata exhibits extraoral feeding (McClintock et al. 1983). This behavior is unique among the Paxillosid sea stars, affording L. clathrata the potential advantage of exploiting detrital food resources in addition to infauna and epifauna. Moreover, it suggests a possible evolutionary link between luidiid sea stars and higher taxa with more complex digestive anatomy (McClintock et al. 1983). Whether the microbial community associated with the gut of $L$. clatharata is also representative of an evolutionary branch between the guts of intraoral and extraoral sea stars remains to be determined.

As has been generally reported in the literature to date, gut microbial communities in healthy individuals under non-stressful conditions have been reported to be relatively stable. Lloyd and Pespeni (2018) reported disruption of microbial community stability and decrease in microbial richness in the epidermal body wall of the sea star Pisaster ochraceus with progression of sea star wasting disease. This stability was similarly observed in the gut microbial community of the sea urchin Lytechinus variegatus exposed to near-future ocean warming (Brothers et al. 2018). Stomach bacterial community structure in $L$. clathrata in the present study was altered by exposure to projected near-future warming. This is consistent with the presumption stress allows for disruption of microbial community structure as opportunistic pathogenic bacteria flourish at the expense of previously stable communities comprised of a few bacterial taxa. Stressors such as increased seawater temperature are known to disrupt microbial 
community structure in marine environments and organisms by either increasing or decreasing overall diversity (e.g., Brothers et al. 2018; Li et al. 2018; Ramsby et al. 2018; Alma et al. 2020; Botté et al. 2020; Greenspan et al. 2020).

\section{Conclusions}

In the present study we report the first account of a sea star gut microbiome community reacting to projected ocean warming in a common sea star. Moreover, this is the first description of the gut microbiome in a sea star from a primitive Asteroid (family Luidiidae). The microbial community of the tissues of the cardiac stomach of the common soft bottom sea star Luidia clathrata was determined to be distinct from that of formulated feed, sand, and seawater that to which sea stars in the experimental study were exposed. Of these four sample types, the stomach microbial community had the lowest overall diversity, with the order Vibrionales, Vibrio in particular, dominating the microbiome across all three temperature treatments $\left(28,30,32^{\circ} \mathrm{C}\right)$. The shift in stomach microbiome to include higher proportions of Delftia and Pseudomonas at $32^{\circ} \mathrm{C}$ is of note as Vibrio, Delftia, and Pseudomonas can all be opportunistic pathogens with some Pseudomonas having activity against some marine pathogenic Vibrio. Further studies should be conducted to examine the microbial communities of Luidia and other sea stars from the natural environment to see if Vibrio-domination is common in natural microbial communities to determine how much the base community observed in this study might have been influenced by acclimatization to aquarium conditions.

\section{Declarations}

\section{Compliance with Ethical Standards}

Ethics approval Not applicable.

Consent to participate Not applicable.

Consent for publication Not applicable.

\section{Acknowledgments}

We thank Sabrina Heiser for her valuable assistance with sample processing. We also thank Dr. CJ Brothers, Liam Van Der Pol, Dr. Guido Bonthond, and Dr. Stacy Kruger-Hadfield for helpful discussion of experimental preparation and data analysis methods. We are grateful to Dr. Charles Amsler and Maggie Amsler for use of laboratory facilities and equipment. We thank the reviewers for their suggestions. This research was funded by an Endowed University Professorship in Polar and Marine Biology to Dr. James McClintock.

\section{Funding}


This research was funded by an Endowed University Professorship in Polar and Marine Biology to Dr. James McClintock.

\section{Conflicts of interest/Competing interests}

The authors have no conflicts of interest or competing interests to declare.

\section{Data/Code availability}

Data will be provided upon reasonable request to the corresponding author [MDC]. A document outlining the code used in analysis of the data for this project has been included as an electronic supplementary file.

\section{Authors' contributions}

MDC and JBM conceived the study. MDC conducted the experiments, analyzed the data, and provided the early draft of the manuscript. CDM oversaw and facilitated the microbiome sample processing and data generation. MDC, JBM, and CDM worked together on later drafts to develop this manuscript.

\section{References}

Alma L, Kram KE, Holtgrieve GW, Barbarino A, Fiamengo CJ, Padilla-Gamiño JL (2020) Ocean acidification and warming effects on the physiology, skeletal properties, and microbiome of the purplehinge rock scallop. Comp Biochem Physiol A Mol Integr Physiol 240:110579. https://doi.org/10.1016/j.cbpa.2019.110579

Andree KB, Rodgers CJ, Furones D, Gisbert E (2013) Co-infection with Pseudomonas anguilliseptica and Delftia acidovorans in the European eel, Anguilla anguilla (L.): A case history of an illegally trafficked protected species. J Fish Dis 36(7):647-656. https://doi.org/10.1111/jfd.12066

Arp A, Munyaneza JE, Crosslin JM, Trumble J, Bextine B (2014) A global comparison of Bactericera cockerelli (Hemiptera: Triozidae) microbial communities. Environ Entomol 43(2):344-352. https://doi.org/10.1603/EN13256

Barker MF, Scheibling RE (2008) Rates of fission, somatic growth and gonadal development of a fissiparous sea star, Allostichaster insignis, in New Zealand. Mar Biol 153:815-824. https://doi.org/10.1007/s00227-007-0854-2

Barker MF, Scheibling R, Mladenov P (1992) Seasonal changes in population structure of the fissiparous asteroids Allostichaster insignis (Farquhar) and Coscinasterias calamaria (Gray). In: Scalera-Liaci L, Canicatti C (eds) Echinoderm Research 1991. AA Balkema, Rotterdam, Netherlands, pp 191-195

Bates AE, Hilton BJ, Harley CDG (2009) Effects of temperature, season and locality on wasting disease in the keystone predatory sea star Pisaster ochraceus. Dis Aquat Organ 86:245-251. 
Bokulich NA, Kaehler BD, Rideout JR, Dillon M, Bolyen E, Knight R, Huttley GA, Gregory Caporaso J (2018) Optimizing taxonomic classification of marker-gene amplicon sequences with QIIME 2's q2-featureclassifier plugin. Microbiome 6:90. https://doi.org/10.1186/s40168-018-0470-z

Bolyen E, Rideout JR, Dillon MR, Bokulich NA, Abnet CC, Al-Ghalith GA, Alexander H, Alm EJ, Arumugam M, Asnicar F, Bai Y, Bisanz JE, Bittinger K, Brejnrod A, Brislawn CJ, Brown CT, Callahan BJ, CaraballoRodríguez AM, Chase J, Cope EK, Da Silva R, Diener C, Dorrestein PC, Douglas GM, Durall DM, Duvallet C, Edwardson CF, Ernst M, Estaki M, Fouquier J, Gauglitz JM, Gibbons SM, Gibson DL, Gonzalez A, Gorlick K, Guo J, Hillmann B, Holmes S, Holste H, Huttenhower C, Huttley GA, Janssen S, Jarmusch AK, Jiang L, Kaehler BD, Kang KB, Keefe CR, Keim P, Kelley ST, Knights D, Koester I, Kosciolek T, Kreps J, Langille MGI, Lee J, Ley R, Liu Y-X, Loftfield E, Lozupone C, Maher M, Marotz C, Martin BD, McDonald D, Mclver LJ, Melnik AV, Metcalf JL, Morgan SC, Morton JT, Naimey AT, Navas-Molina JA, Nothias LF, Orchanian SB, Pearson T, Peoples SL, Petras D, Preuss ML, Pruesse E, Rasmussen LB, Rivers A, Robeson MS, Rosenthal P, Segata N, Shaffer M, Shiffer A, Sinha R, Song SJ, Spear JR, Swafford AD, Thompson LR, Torres PJ, Trinh P, Tripathi A, Turnbaugh PJ, Ul-Hasan S, van der Hooft JJJ, Vargas F, Vázquez-Baeza Y, Vogtmann E, von Hippel M, Walters W, Wan Y, Wang M, Warren J, Weber KC, Williamson CHD, Willis AD, Xu ZZ, Zaneveld JR, Zhang Y, Zhu Q, Knight R, Caporaso JG (2019) Reproducible, interactive, scalable and extensible microbiome data science using QIIME 2. Nat Biotechnol 37:852-857. https://doi.org/10.1038/s41587-019-0209-9

Bosch I (1992) Symbiosis between bacteria and oceanic clonal sea star larvae in the western North Atlantic Ocean. Mar Biol 114:495-502. https://doi.org/10.1007/BF00350041

Botté ES, Luter HM, Marangon E, Patel F, Uthicke S, Webster NS (2020) Simulated future conditions of ocean warming and acidification disrupt the microbiome of the calcifying foraminifera Marginopora vertebralis across life stages. Environ Microbiol Rep 12(6):693-701. https://doi.org/10.1111/17582229.12900

Bourne DG, Morrow KM, Webster NS (2016) Insights into the coral microbiome: Underpinning the health and resilience of reef ecosystems. Annu Rev Microbiol 70:317-340. https://doi.org/10.1146/annurevmicro-102215-095440

Brothers CJ, Van Der Pol WJ, Morrow CD, Hakim JA, Koo H, McClintock JB (2018) Ocean warming alters predicted microbiome functionality in a common sea urchin. Proc R Soc B Biol Sci 285:20180340. https://doi.org/10.1098/rspb.2018.0340

Callahan BJ, McMurdie PJ, Rosen MJ, Han AW, Johnson AJA, Holmes SP (2016) DADA2: High-resolution sample inference from Illumina amplicon data. Nat Methods 13:581-583.

https://doi.org/10.1038/nmeth.3869 
Caporaso JG, Lauber CL, Walters WA, Berg-Lyons D, Huntley J, Fierer N, Owens SM, Betley J, Fraser L, Bauer M, Gormley N, Gilbert JA, Smith G, Knight R (2012) Ultra-high-throughput microbial community analysis on the Illumina HiSeq and MiSeq platforms. ISME J 6:1621-1624.

https://doi.org/10.1038/ismej.2012.8

Carrier TJ, Wolfe K, Lopez K, Gall M, Janies DA, Byrne M, Reitzel AM (2018) Diet-induced shifts in the crown-of-thorns (Acanthastersp.) larval microbiome. Mar Biol 165:157. https://doi.org/10.1007/s00227018-3416-x

Chythanya R, Karunasagar I, Karunasagar I (2002) Inhibition of shrimp pathogenic vibrios by a marine Pseudomonas I-2 strain. Aquaculture 208(1-2):1-10. https://doi.org/10.1016/S0044-8486(01)00714-1

D'Argenio V, Salvatore F (2015) The role of the gut microbiome in the healthy adult status. Clin Chim Acta 451(A):97-102. https://doi.org/10.1016/j.cca.2015.01.003

Dilmore LA, Hood MA (1986) Vibrios of some deep-water invertebrates. FEMS Microbiol Lett 35(23):221-224. https://doi.org/10.1111/j.1574-6968.1986.tb01531.x

Eckert GL, Engle JM, Kushner DJ (1999) Sea star disease and population declines at the Channel Islands. Proc Fifth Channel Isl Symp 390-393

Egan S, Gardiner M (2016) Microbial dysbiosis: Rethinking disease in marine ecosystems. Front Microbiol 7:991. https://doi.org/10.3389/fmicb.2016.00991

Eisenlord ME, Groner ML, Yoshioka RM, Elliott J, Maynard J, Fradkin S, Turner M, Pyne K, Rivlin N, van Hooidonk R, Harvell CD (2016) Ochre star mortality during the 2014 wasting disease epizootic: Role of population size structure and temperature. Philos Trans R Soc B Biol Sci 371:20150212.

https://doi.org/10.1098/rstb.2015.0212

Fly EK, Monaco CJ, Pincebourde S, Tullis A (2012) The influence of intertidal location and temperature on the metabolic cost of emersion in Pisaster ochraceus. J Exp Mar Biol Ecol 422-423:20-28. https://doi.org/10.1016/j.jembe.2012.04.007

Foster MC, Byrnes JEK, Reed DC (2015) Effects of five southern California macroalgal diets on consumption, growth, and gonad weight, in the purple sea urchin Strongylocentrotus purpuratus. PeerJ 3:e719. https://doi.org/10.7717/peerj.719

Gao F, Li F, Tan J, Yan J, Sun H (2014) Bacterial community composition in the gut content and ambient sediment of sea cucumber Apostichopus japonicus revealed by $16 \mathrm{~S}$ rRNA gene pyrosequencing. PLoS ONE 9(6):e100092. https://doi.org/10.1371/journal.pone.0100092

George S, Lawrence J, Fenaux L (1990) Effect of starvation and the time to first feeding on larvae of Luidia clathrata. In: De Rider, Dubois, Lahaye, Jangoux (eds) Echinoderm research. AA Balkema, Rotterdam, Netherlands, pp 91-98 
Gomez A, Espinoza JL, Harkins DM, Leong P, Saffery R, Bockmann M, Torralba M, Kuelbs C, Kodukula R, Inman J, Hughes T, Craig JM, Highlander SK, Jones MB, Dupont CL, Nelson KE (2017) Host genetic control of the oral microbiome in health and disease. Cell Host Microbe 22(3):269-278.e3. https://doi.org/10.1016/j.chom.2017.08.013

Gooding RA, Harley CD, Tang E (2009) Elevated water temperature and carbon dioxide concentration increase the growth of a keystone echinoderm. Proc Natl Acad Sci 106(23):9316-9321. https://doi.org/10.1073/pnas.0811143106

Greenspan SE, Migliorini GH, Lyra ML, Pontes MR, Carvalho T, Ribeiro LP, Moura-Campos D, Haddad CFB, Toledo LF, Romero GQ, Becker CG (2020) Warming drives ecological community changes linked to hostassociated microbiome dysbiosis. Nat Clim Change 10:1057-1061. https://doi.org/10.1038/s41558-0200899-5

Gudenkauf BM, Hewson I (2015) Metatranscriptomic analysis of Pycnopodia helianthoides (Asteroidea) affected by sea star wasting disease. PLoS ONE 10(5):e0128150.

https://doi.org/10.1371/journal.pone.0128150

Guerinot ML, Patriquin DG (1981) $\mathrm{N}_{2}$-fixing vibrios isolated from the gastrointestinal tract of sea urchins. Can J Microbiol 27(3):311-317. https://doi.org/10.1139/m81-048

Hakim JA, Koo H, Kumar R, Lefkowitz EJ, Morrow CD, Powell ML, Watts SA, Bej AK (2016) The gut microbiome of the sea urchin, Lytechinus variegatus, from its natural habitat demonstrates selective attributes of microbial taxa and predictive metabolic profiles. FEMS Microbiol Ecol 92(9):fiw146. https://doi.org/10.1093/femsec/fiw146

Haramoto S, Komatsu M, Yamazaki Y (2007) Patterns of asexual reproduction in the fissiparous seastar Coscinasterias acutispina (Asteroidea: Echinodermata) in Japan. Zoolog Sci 24(11):1075-1081. https://doi.org/10.2108/zsj.24.1075

Harvell CD, Mitchell CE, Ward JR, Altizer S, Dobson AP, Ostfeld RS, Samuel MD (2002) Climate warming and disease risks for terrestrial and marine biota. Science 296:2158-2162.

https://doi.org/10.1126/science.1063699

Harvell CD, Montecino-Latorre D, Caldwell JM, Burt JM, Bosley K, Keller A, Heron SF, Salomon AK, Lee L, Pontier O, Pattengill-Semmens C, Gaydos JK (2019) Disease epidemic and a marine heat wave are associated with the continental-scale collapse of a pivotal predator (Pycnopodia helianthoides). Sci Adv 5:eaau7042. https://doi.org/10.1126/sciadv.aau7042

Hendler G, Miller JE, Pawson DL, Kier PM (1995) Sea stars, sea urchins, and allies: Echinoderms of Florida and the Caribbean. Smithsonian Institution Press, Washington 
Høj L, Levy N, Baillie BK, Clode PL, Strohmaier RC, Siboni N, Webster NS, Uthicke S, Bourne DG (2018) Crown-of-thorns sea star Acanthaster cf. solaris has tissue-characteristic microbiomes with potential roles in health and reproduction. Appl Environ Microbiol 84(13):e00181-18, https://doi.org/10.1128/AEM.00181-18

Holland ND (2013) Digestive system in regular sea urchins. In: Lawrence JM (ed) Sea urchins: Biology and ecology, $3^{\text {rd }}$ edn. Elsevier, London, pp 119-133

Holmes E, Li JV, Athanasiou T, Ashrafian H, Nicholson JK (2011) Understanding the role of gut microbiome-host metabolic signal disruption in health and disease. Trends Microbiol 19(7):349-359. https://doi.org/10.1016/j.tim.2011.05.006

Huq A, Huq SA, Grimes DJ, O'Brien M, Chu KH, Capuzzo JM, Colwell RR (1986) Colonization of the gut of the blue crab (Callinectes sapidus) by Vibrio cholerae. Appl Environ Microbiol 52(3):586-588. https://doi.org/10.1128/AEM.52.3.586-588.1986

Jackson EW, Pepe-Ranney C, Debenport SJ, Buckley DH, Hewson I (2018) The microbial landscape of sea stars and the anatomical and interspecies variability of their microbiome. Front Microbiol 9:1829. https://doi.org/10.3389/fmicb.2018.01829

Jangoux M (1982) Food and feeding mechanisms: Asteroidea. In: Jangoux M, Lawrence JM (eds) Echinoderm nutrition. AA Balkema, Rotterdam, Netherlands, pp 117-159

Jayatilake GS, Thornton MP, Leonard AC, Grimwade JE, Baker BJ (1996) Metabolites from an Antarctic Sponge-Associated Bacterium, Pseudomonas aeruginosa. J Nat Prod 59(3):293-296.

https://doi.org/10.1021/np960095b

Kinross JM, Darzi AW, Nicholson JK (2011) Gut microbiome-host interactions in health and disease. Genome Med 3:14. https://doi.org/10.1186/gm228

KohI WT, McClure TI, Miner BG (2016) Decreased temperature facilitates short-term sea star wasting disease survival in the keystone intertidal sea star Pisaster ochraceus. PLoS ONE 11:e0153670. https://doi.org/10.1371/journal.pone.0153670

Kozich JJ, Westcott SL, Baxter NT, Highlander SK, Schloss PD (2013) Development of a dual-index sequencing strategy and curation pipeline for analyzing amplicon sequence data on the MiSeq Illumina sequencing platform. Appl Environ Microbiol 79:5112-5120. https://doi.org/10.1128/AEM.01043-13

Kumar R, Eipers P, Little RB, Crowley M, Crossman DK, Lefkowitz EJ, Morrow CD (2014) Getting started with microbiome analysis: Sample acquisition to bioinformatics. Curr Protoc Hum Genet 14(82):18.8.129. https://doi.org/10.1002/0471142905.hg1808s82 
Larsen T, Ventura M, Maraldo K, Triadó-Margarit X, Casamayor EO, Wang YV, Andersen N, O’Brien DM (2016) The dominant detritus-feeding invertebrate in Arctic peat soils derives its essential amino acids from gut symbionts. J Anim Ecol 85(5):1275-1285. https://doi.org/10.1111/1365-2656.12563

Lawrence JM (2013) Starfish: Biology and ecology of the Asteroidea. JHU Press, Baltimore

Lawrence JM, Durán-González A, Solís-Marín FA, Herrera J, Ventura CRR (2013) Distribution of Luidia clathrata and Luidia lawrencei (Echinodermata: Asteroidea) along the coast of the western Atlantic Ocean, the Gulf of Mexico and the Caribbean Sea. Cah Biol Mar 54:525-529.

Li Y-F, Yang N, Liang X, Yoshida A, Osatomi K, Power D, Batista FM, Yang J-L (2018) Elevated seawater temperatures decrease microbial diversity in the gut of Mytilus coruscus. Front Physiol 9:839. https://doi.org/10.3389/fphys.2018.00839

Lloyd MM, Pespeni MH (2018) Microbiome shifts with onset and progression of sea star wasting disease revealed through time course sampling. Sci Rep 8:16476. https://doi.org/10.1038/s41598-018-34697-w

Lokmer A, Mathias Wegner K (2015) Hemolymph microbiome of Pacific oysters in response to temperature, temperature stress and infection. ISME J 9:670-682.

https://doi.org/10.1038/ismej.2014.160

Lynch JB, Hsiao EY (2019) Microbiomes as sources of emergent host phenotypes. Science 365(6460):1405-1409. https://doi.org/10.1126/science.aay0240

McClintock JB, Klinger TS, Lawrence JM (1983) Extraoral feeding in Luidia clathrata (Say) (Echinodermata: Asteroidea). B Mar Sci 33(1):171-172

McClintock JB, Lawrence JM (1981) An optimization study on the feeding behavior of Luldia clathrata say (Echinodermata: Asteroidea). Mar Behav Physiol 7(4):263-275.

https://doi.org/10.1080/10236248109386987

Monaco CJ, Wethey DS, Helmuth B (2014) A dynamic energy budget (DEB) model for the keystone predator Pisaster ochraceus. PLoS ONE 9:e104658. https://doi.org/10.1371/journal.pone.0104658

Pagán-Jiménez M, Ruiz-Calderón JF, Dominguez-Bello MG, García-Arrarás JE (2019) Characterization of the intestinal microbiota of the sea cucumber Holothuria glaberrima. PLoS ONE 14:e0208011.

https://doi.org/10.1371/journal.pone.0208011

Parmesan C (2006) Ecological and evolutionary responses to recent climate change. Annu Rev Ecol Evol Syst 37:637-669. https://doi.org/10.1146/annurev.ecolsys.37.091305.110100

Peck LS, Webb KE, Miller A, Clark MS, Hill T (2008) Temperature limits to activity, feeding and metabolism in the Antarctic starfish Odontaster validus. Mar Ecol Prog Ser 358:181-189.

https://doi.org/10.3354/meps07336

Page 19/23 
Pörtner HO (2002) Climate variations and the physiological basis of temperature dependent biogeography: Systemic to molecular hierarchy of thermal tolerance in animals. Comp Biochem Physiol A Mol Integr Physiol 132:739-761. https://doi.org/10.1016/S1095-6433(02)00045-4

Pörtner HO (2008) Ecosystem effects of ocean acidification in times of ocean warming: a physiologist's view. Mar Ecol Prog Ser 373:203-217. https://doi.org/10.3354/meps07768

Preheim SP, Boucher Y, Wildschutte H, David LA, Veneziano D, Alm EJ, Polz MF (2011) Metapopulation structure of Vibrionaceae among coastal marine invertebrates. Environ Microbiol 13(1):265-275. https://doi.org/10.1111/j.1462-2920.2010.02328.x

Przeslawski R, Ahyong S, Byrne M, Wörheide G, Hutchings P (2008) Beyond corals and fish: The effects of climate change on noncoral benthic invertebrates of tropical reefs. Glob Change Biol 14(12):2773-2795. https://doi.org/10.1111/j.1365-2486.2008.01693.x

Quast C, Pruesse E, Yilmaz P, Gerken J, Schweer T, Yarza P, Peplies J, Glöckner FO (2012) The SILVA ribosomal RNA gene database project: improved data processing and web-based tools. Nucleic Acids Res 41(D1):D590-D596. https://doi.org/10.1093/nar/gks1219

Ramsby BD, Hoogenboom MO, Whalan S, Webster NS (2018) Elevated seawater temperature disrupts the microbiome of an ecologically important bioeroding sponge. Mol Ecol 27(8):2124-2137. https://doi.org/10.1111/mec.14544

Schiel DR, Steinbeck JR, Foster MS (2004) Ten years of induced ocean warming causes comprehensive changes in marine benthic communities. Ecology 85(7):1833-1839. https://doi.org/10.1890/03-3107

Shreiner AB, Kao JY, Young VB (2015) The gut microbiome in health and in disease. Curr Opin Gastroenterol 31(1):69-75. https://doi.org/10.1097/MOG.0000000000000139

Simon CJ, Truong HH, Noble TH, Osborne SA, Wynne JW, Wade NM (2020) Microbial biomass, marine invertebrate meals and feed restriction influence the biological and gut microbiota response of shrimp Penaeus monodon. Aquaculture 520:734679. https://doi.org/10.1016/j.aquaculture.2019.734679

Sochard MR, Wilson DF, Austin B, Colwell RR (1979) Bacteria associated with the surface and gut of marine copepods. Appl Environ Microbiol 37:750-759. https://doi.org/10.1128/AEM.37.4.750-759.1979

Spor A, Koren O, Ley R (2011) Unravelling the effects of the environment and host genotype on the gut microbiome. Nat Rev Microbiol 9:279-290. https://doi.org/10.1038/nrmicro2540

Thao ML, Moran NA, Abbot P, Brennan EB, Burckhardt DH, Baumann P (2000) Cospeciation of Psyllids and Their Primary Prokaryotic Endosymbionts. Appl Environ Microbiol 66:2898-2905. https://doi.org/10.1128/AEM.66.7.2898-2905.2000 
Tracy AM, Pielmeier ML, Yoshioka RM, Heron SF, Harvell CD (2019) Increases and decreases in marine disease reports in an era of global change. Proc R Soc B Biol Sci 286:20191718.

https://doi.org/10.1098/rspb.2019.1718

Vuong HE, Yano JM, Fung TC, Hsiao EY (2017) The Microbiome and host behavior. Annu Rev Neurosci 40:21-49. https://doi.org/10.1146/annurev-neuro-072116-031347

Watts SA, Lawrence JM (1986) Seasonal effects of temperature and salinity on the organismal activity of the seastar Luidia clathrata (say) (Echinodermata: Asteroidea). Mar Behav Physiol 12(3):161-169. https://doi.org/10.1080/10236248609378643

Watts SA, Lawrence JM (1990) The effect of temperature and salinity interactions on righting, feeding and growth in the sea star Luidia clathrata (SAY). Mar Behav Physiol 17(3):159-165.

https://doi.org/10.1080/10236249009378765

Webster NS, Thomas T (2016) The sponge hologenome. mBio 7:e00135-16.

https://doi.org/10.1128/mBio.00135-16

Zhou G, Cai L, Yuan T, Tian R, Tong H, Zhang W, Jiang L, Guo M, Liu S, Qian P-Y, Huang H (2017) Microbiome dynamics in early life stages of the scleractinian coral Acropora gemmifera in response to elevated pCO2. Environ Microbiol 19(8):3342-3352. https://doi.org/10.1111/1462-2920.13840

\section{Figures}




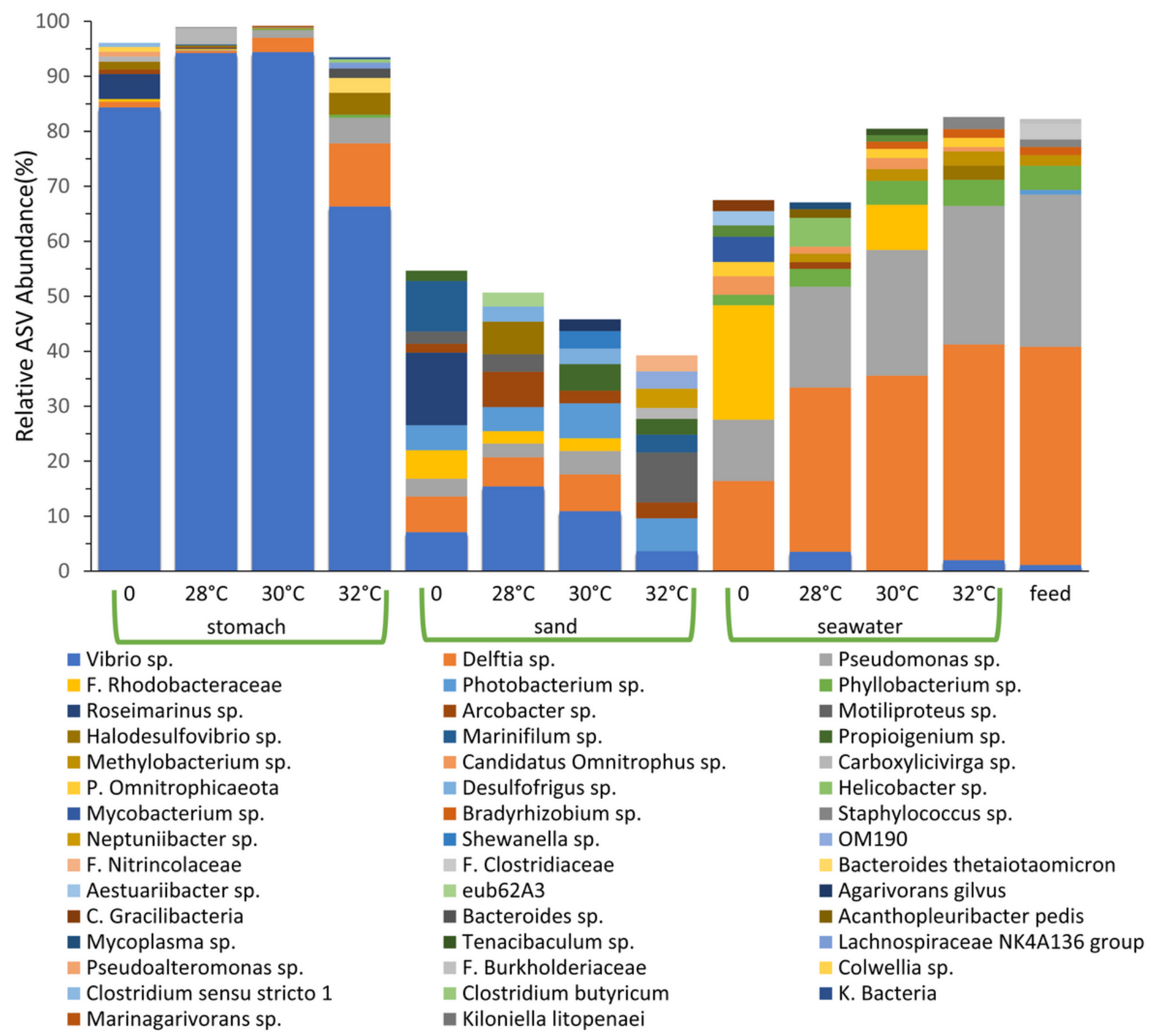

\section{Figure 1}

Relative abundance of the ten most abundant amplicon sequence variants (ASVs) from samples of feed and Luidia clathrata stomach, seawater, sand, and feed at time zero and after two-week exposure to warming. ASVs binned and taxonomy assigned using Qiime2, data sorted and stacked bar chart constructed using Excel. Taxa represented by the most resolved level based on SILVA9 (v132) taxonomic classification 
Axis $2(22.47 \%)$

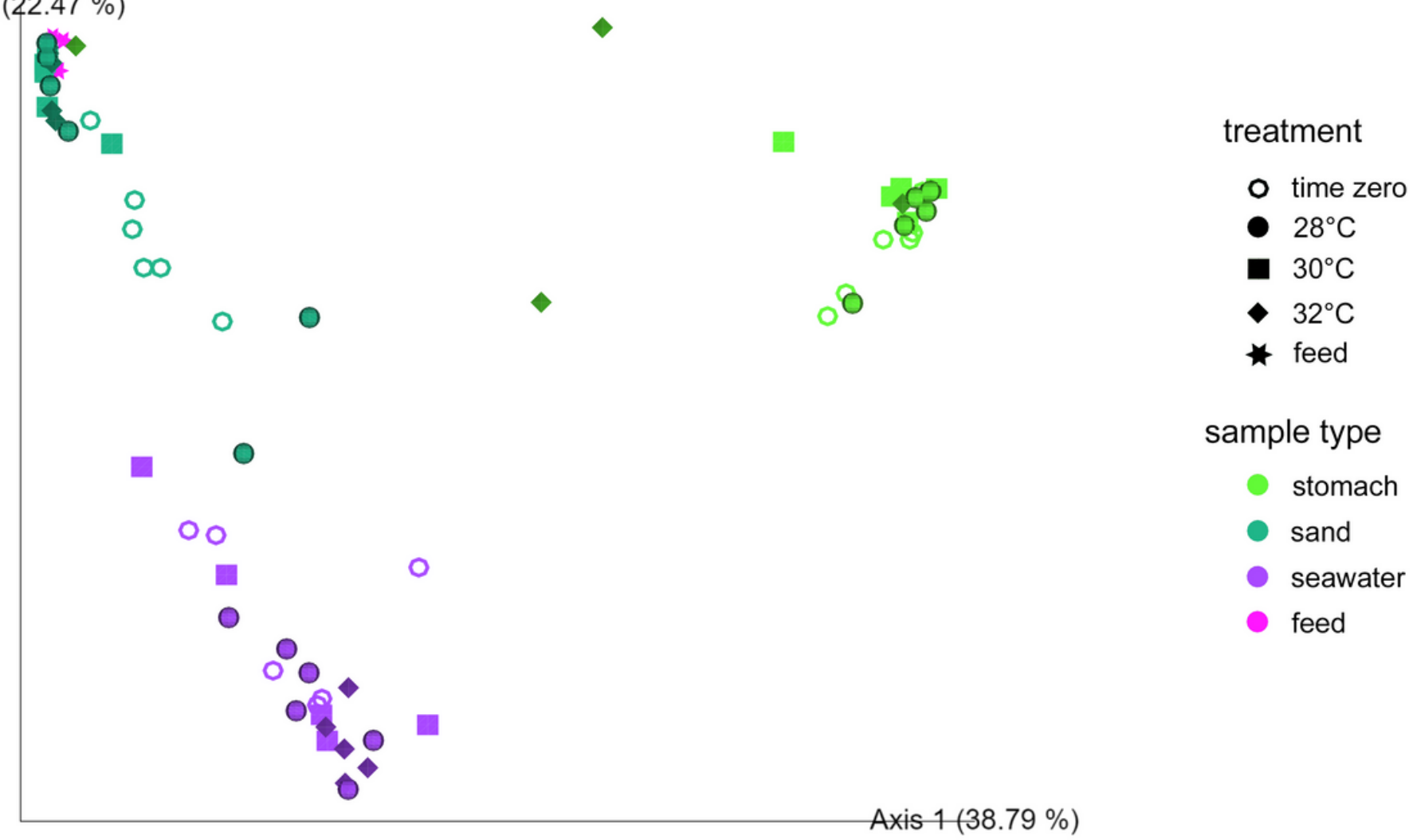

Figure 2

2-dimensional principal component analysis ( $\mathrm{PCOA}$ ) plot of Bray-Curtis dissimilarity for feed, and stomach, sand, and seawater samples for Luidia clathrata at time zero and held under $28^{\circ} \mathrm{C}, 30^{\circ} \mathrm{C}$, and $32^{\circ} \mathrm{C}$ for 2 weeks. Axis 1 explains $38.79 \%$ variance and axis 2 explains $22.47 \%$. Graphed with Qiime2

\section{Supplementary Files}

This is a list of supplementary files associated with this preprint. Click to download.

- ESM1.pdf 